The human race is greatly handicapped by the presence of a good number of people who strenuously object to being disturbed. During a decade, generation, or century these good but sometimes unpleasant people plant themselves along certain lines in the domain of science or politics or religion, proclaiming essentially that "here and here only is the truth, and here we fix ourselves forever." After awhile they somewhat unwillingly and with no very good grace move forward into a new position, again honestly affirming and believing that the end has been reached. A better knowledge and a broader human sympathy would reveal to them the hitherto unsuspected fact that truth may at the same time be here and there.

In the dissemination of this knowledge and the cultivation of this sympathy, science should lead, not follow. No scientific organization so young in years has done more along these lines, especially by reason of its extensive membership and the vigor and enthusiasm of its branches, than the society over whose deliberations during the past year I have been permitted to preside.

For the honor thus bestowed I beg now to make my formal and grateful acknowledgements.

\section{REMARKS UPON THE GRAPHIC SYSTEM OF THE} ANCIENT MAYAS.

BY HILbORNE T. CRESSON, A.M., M.D.

A MAYA hieroglyph may be a single character by which a meaning is expressed by the sound of the name of the thing represented, or it may have a number of components that convey by a similar method a series of ideas. The 'glyphs of Kukuitz and of Cauac in the Codex Troano are examples, and another is that over the figure of Kukulcan, or Ikilcab, the so-called long-nosed god, of whom representations appear so frequently in the different Maya codices.

The figures of gods, with their head-dresses and the objects represented by the Maya scribes in the Codex Troano and other manuscripts, may be composed of a series of hieroglyphic elements suggesting the names of gods and their attributes or of some of the various characters which they impersonate. An example of this is the head-dress of the long-nosed god of the Codex Troano, which reads Ikilcab, while his girdle expresses by phonetic elements the name Kukuitz, who seems also to have been Kukulcan, Ikilcab or Cauac, and Itzamna. It is not improbable that Kukuitz, Kukulcan, Ikilcab, and Itzamna is the Hunakbu, or one God spoken of in the Codex Troano and referred to on the hieratic tablets, Casa No. 2, Palenque.

I notice that in the photographs of the ancient cities of Yucatan and other portions of Central America, that which we have hitherto considered as architectural ornamentation of Maya design is ikonomatic decoration, and a notable instance is the name Chi-chen-itza on the palaces of that ancient city, which are repeatedly recalled by Chi and itza, and less frequently by repetitions of the word Chen. I make this assertion subject to further alteration and improvement, as I have not examined the buildings themselves, being obliged to depend upon bad photographs and still worse wood-cuts.

The hieroglyphs and ikonomatic ornamentations of $\mathrm{Pa}-$ lenque, Chi-chen.itza, Labna, Tikul, Lorillard City, and Copan, judging by photographs taken at these places, seem to be allied to one another, but those of Uxmal are more archaic, with the exception of Copan.
The plan I have adopted in my analysis of the various components of a'glyph, those standing for the sounds of the names of the things represented, is based upon the idea that the Maya script, both hieratic and demotic, is similar to the bigher grade of picture-writing suggested by M. Aubin, in his analysis of the name Itz-co-atl, - represented by the conventional sign for water, obsidian attachments to the shaft of the arrow, and a vase or pot,- which by reference to his work will more fully appear.

Proceeding upon this plan, I endeavored to analyze Landa's Key, and have found that the Maya scribe simply gave 'glyphs, whether simple or combined together, that carried out Landa's pronunciation of the Spanish alphabet, by means of characters which stood for the sounds of the names of these letters.

The hieroglyph of a tarantula or centipede, figured in the Troano plates - a claw pinching a rope attached to the foot of a deer-like animal, and also a hand attached to the same insect-like figure in the act of pinching - suggested the various curved 'glyphs of the verb $C^{h} i$ (Maya, to bite), which are, I believe, in connection with the parrot 'glyph, Moo, a part of the primitive elements of the Maya alphabet. From this I have obtained Chá, Chā (or Che), Chi, Cho, Chu, and from the Moo (parrot) 'glyph has been obtained a, e, i, o, u. This system has been applied successfully to the rendering of the components of the day-signs of the Troano manuscript and those of the Chilan Balaam of Káua, using Dr. Brinton's plates for the work - those published in his essay upon the books of "Chilan Balaam," pages 16 and 17.

In several cases certain 'glyphs, such as that of Ikilcab, Cauac, and Itzamna, have suggested meanings so clearly expressed that the words were easily found in the vacubulary of the Abbe Brasseur de Bourbourg, and had such a strong resemblance to objects and 'glyphs carried by the figures to which they belonged, that I venture to think the alphabet which I have arranged will eventually work successfully. It is based upon studies of the hieratic script made while at the Ecole de Beaux Arts in 1875-76-7\%, and work done on the Troano script in 1880 ; these researches being thrown aside and recommenced since Jan. 1, 1892.

Although Dr. Thomas and myself have proceeded in methods totally different from each other, and have never yet met to make comparisons, in quite a number of cases our methods have shown like results. I have mailed Professor D. G. Brinton, and the first-named gentleman, proof of this similarity of interpretation, and may also add that before I received a copy of Professor Thomas's "Key" I had mailed, and I venture to say both these gentlemen had received, my analysis and arrangement of the Maya signs of orientation, viz., Chikin, West; Lakin, East; Schaman, North; Nohol, South. My arrangement of these signs corresponds to that of de Rosny and Thomas. The first sign of orientation on the list was determined by the $\mathrm{C}^{\mathrm{h}} \mathrm{i}$ 'glyph.

I mention the correspondence of my work with that of Professor Thomas to show that this similarity of interpretation, referred to, cannot be the result of mere guesswork.

The aspirates and signs of repetition and the determinatives of the Maya Graphic System are most important, and I give them as Landa expresses it, and also by dotted lines in circles and curves. The phonetic value of the curve in the Maya alphabet is one of its strongest elements. Most of the characters in the key I have arranged are based on it and other natural suggestions of animate and inanimate nature- 
such as the parrot eye, the biting mouth, and the mole-like teeth, the curved line of the serpent's body, and the beautiful outlines of the antennoe of the bee, also its sting, and last, not least, the graceful leaf of the maize, and other natural forms which are symbols of fertility.

It may be interesting to remark that the phonetic value of the antennoe of the bee was suggested by the third 'glyph, Cauac, on the Kukuitz bas-relief, left-hand side of the Casa No. 3, Palenque. This 'glyph was traced to more demotic forms on plate 25 of the Troano, also plate 24 , where it is upheld by the Goddess $C a b$. Near the figure of $C a b$ is the same infant-like figure that is to be seen on the so-called tablet of the cross of Palenque. The component characters of the 'glyphs composing this child's body refer to his name as Ikilcab, and this same name is expressed on the headdress and hieroglyphs of the God-with-the-long-nose of the Troano, and other manuscripts, so-called by students to distinguish him. Ikilcab and Cauac, the Cuch-haab, are in some way clearly connected, for the components of the Cauac 'glyph of the day-signs of Landa and those of the Chilan Balaam of Kaua are closely connected with those of Caban. The Cauac 'glyph, if my interpretation be correct, reads Ikilcab. The ancient Mayas probably thought of the bee as Ikil, the sting, and $C a b$, honey. The 'glyph of the day-sign, Caban, refers to that day-sign and Ikilcab, and is also the honey sign ("Bee Keeper's Narrative," the Codex Troano). The numeral signs of the Troana, both red and black, seem to have been used at times ikonomatically. The serpent symbol on plate 25 , division 1 , Troano, is $C^{a} a n$, and close to it are numerals giving the suggestion Hunakbu, the one God. On the sun symbol of this plate are numerals, which, in connection with the flute 'glyph (Chul) projecting above the sun-disk and the hand below pinching the machete, suggest the interpretation "a name," Chu.kul-cocan.

Alliteration and syncapation for the sake of euphony are especially noticeable in the Maya language, but do not seem to be followed in the arrangement of their graphic characters, and no regularity of procedure, in reading the component parts of a 'glyph, seems to exist. As a general thing, however, some object carried in the hand of a figure, or placed near it, serves as a sort of a determination or suggestion; this is more frequently the case in the demotic than hieratic script.

\begin{tabular}{|c|}
\hline Publications Received at Editor's Office. \\
\hline 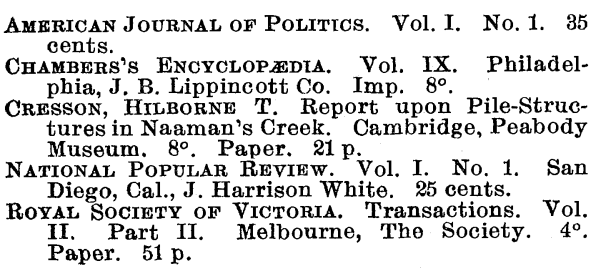 \\
\hline
\end{tabular}

Reading Matter Notices.

Ripans Tabules cure jaundice.

\section{Societas Entomologica.}

International Entomological Society, $Z_{u}$ rich-Hottingen, Switzerland. Annual fee, ten francs.

The Journal of the Society appears twice a month, and consists entirely of original articles on entomology, with a department for advertisements. All members may use this department free of cost for advertisements relating to entomology.

The Society consists of about $\mathbf{4 5 0}$ member in all countries of the world.

The new volume began April 1, 1892. The numbers already issued will be sent to new members.

For information address Mr. Frimz RuBL, President of the Societas Entomologica, Zarieh-Hottingen, Switzerland.

NEO-DARWINISY AND NEO-LAMARCKISM. By LESTER F. WARD.

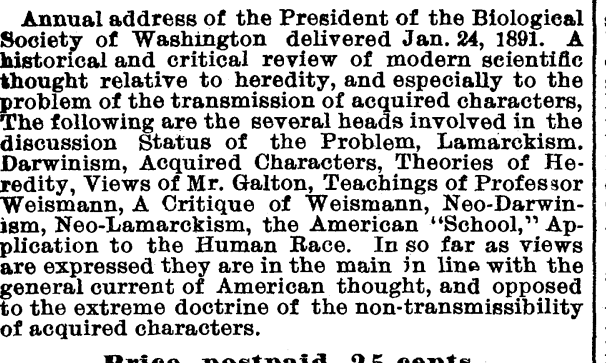

Price, postpaid, 25 cents.

N. D. C. HODGES, 874 Broadway, N. Y.

\section{Exchanges.}

[Free of charge to all, if of satisfactory character. Address N. D. C. Hodges, 874 Broadway, New York.]

Taxidermist going out of business has quantity of finely-mounted specimens of North American birds mammals and reptiles and skins of birds for sale, including a full local collection of bir: skins, showof skulls with horns of deer and mountain sheep and mounted heads of same. Will give good ex change for Hawk Eye camera with outfit. Apply quickly to

For exchange.-A fine thirteen-keyed flute in leather covered case, for a photograph camera suitable for makU. O. COX, Mankato, Minn.

T $\Theta$ exchange; Experiment Station bulletins an reports for bulletins and reports not in my file. will send list of what $I$ have for exchange. $P$. $H$. ROLES, Lake City, Florida.

Finished specimens of all colors of Vermont marble for fine fossils or crystals. Will be given only for valuable specimens because of the cost of polish
PERRY, State Geologist, Rutland, Vt.

For exchange.-Three copies of "American State Papers Bearing on Sunday Legislation," 1891, \$2.50, new and unused, for "The Sabbath," by Harmon Kingsbury, 1840; "The Sabbath," by A. A. Phelps, ${ }^{842}$; " Histor of the Institution of the Sabbath Day, Its Uses and
Abuses," by W. L. Fisher, I 859; "Humorous Phases of
the Law," by Irving Browne; or other works amounting to value of books exchanged, on the question of governmental legislation in reference to religion, personal liberty, etc. If preferred, I will sell "American State Papers," and buy other books on the subject.
DISON BLAKELY, Chicago, Ill.

For Sale or Exchange for books a complete private chemical laboratory outfit. Includes large Becker balance (200g. to 1-10mg.), platinum dishes and crucibles,
agate motors, glass-blowing apparatus, etc. For sale in agate motors, glass-blowing apparatus, etc. For sale in
part or whole. Also complete file of Silliman's fournal, part or whole. Also complete file of Silliman's Fournal
$1862-1885$ (62-71 bound); Smithsonian Reports, $1854-1883$ U. S. Coast Survey 1854-1869. Full particulars
quirers. F. GARDINER, JR., Pomfret, Conn.

Wanted, in exchange for the following works, any standard works on Surgery and on Diseases of Children: standard works on Surgery and on . Diseases of Children:
Wilson's "American Ornithology,, 3 vols.; Coues' "Birds
of the Northwest" and " Birds of the Colorado Valley," land;"; Mamuels' " "Land and Game Birds of New England;'"Samuels' "Our Northern and Eastern Birds;" al bound in 2 vols., morocco; and a complete set of the Reports of the Arkansas Geological Survey, Please give CALL, High School, Des Moines, Iowa.

To exchange Wright's "Ice Age in North America" and Le Conte's "Elements of Geology" (Copyright r882) for "Darwinism," by A. R. Wallace, "Origin of Species," Place in Nature," Huxley, "Mental Evolution in Animals," by Romanes, "Pre-Adamites," by Winchell. No books wanted except latest editions, and books in good condition. C. S. Brown, Jr., Vanderbilt University,
Wants.

Any person seeking a position for which he is qualified by his scientific attainments, or any person seeking some one to fll a position of this character, be it that of a teacher of science, chemist, draughtsman, or what not, may have the 'Want' inserted under this head FREE OF COST, if he satisfies the publisher of the suitinformation of his application. Any person seeking auy scientific man or who can in any way use this column for $a$ purpose consonant with the nature of the paper, is cordially invited to do so.

$W^{\text {ANTED }- \text { A collection of postage stamps; one }}$ W made previous to 1870 preferred. Also old and curious stamps on original letters, and old entire
U S. stamped envelopes. Will pay e ash or give in exchange first-class fossils, including fine crinoids. exchange first-class fossils, includ
WM. F. E. GUR LEY, Danville, Ill.


Wanted immediately for dishes, burettes, etc. wanted immediately for cash. C. E. SP
Murray street, New York. P. O. Box 1741 .

W ANTED.-The services of a wide-awake young man, as eorrespondent, in a large manufacturough knowbedge of microscopy and who has a thorof photography. Address by letter, stating age and
of and references. Optical, care of Science, 874 Broadway, New York.

$W^{\text {ANTED - We want any and sll of the following }}$ Wroviding we can trade other books and magazines or buy them cheap for cash: Academy, London, vol. 1 to 28, 35, Jan. and Feb., 89; Age of Steel,
vol. 1 to $66 ;$ American Antiquarian, vol. 1,$2 ;$ American Architect, vol. 1 to 6, 9; American Art Review
vol. 3; American Field, vol. 1 to 21: American Geolvol. 3; American Field, vol. 1 to 21; American GeolArt Amateur, vol. 1 to 7 , Oet., ' '4; Art Interchange vol. 1 to 9; Art Union, vol. 1 to 4, Jan., '44, July, '45; Bibliotheca Sacra, vol. 1 to 16; Godeg's Lady's Book, vol. 1 to 20 ; New Knglander, vol. 11; Zoologist, Series 1 and 1, Series 3 rol. 1 to 14;, Allen Arraendale (a S., Minneapolis, Minn.

WANTED.-By a young man, a swarthmore ColW lege junior, a position as principal of a publie high school in one of the Gulf States, or as instructor
in botany, physiology, and geology in an academy
or noormai school. Address B, care of tabrarian, Swarthmore College, Penn.

$W^{A N T E D}$ - To act as correspondent for one or two daily or weekly papers. Have worked on
paper for about two years. Would like a position on paperiar about two years. Woular. Address GEO C. MASON, 14 Elm St., Hartford, Conn.

TRANSLATOR wanted to read German architeretural works at sight (no writing). One familiar
with technical terms desired. Address "A.," Box with technical terms des
149, New York Post Office. W ANTED.-A position in a manufacturing estabventive ability. Add
874 Broadway, N. Y. 